\title{
RESEARCH PAPER RP951
}

Part of Journal of Research of the National Bureau of Standards, Volume 17, December 1936

\section{SOME PHYSICAL PROPERTIES OF ISOPRENE}

\section{By Norman Bekkedahl, Lawrence A. Wood, and Mieczysław Wojciechowski ${ }^{1}$}

\section{ABSTRACT}

Isoprene (2-methyl-1,3-butadiene) has been prepared in a state of high purity. Physical properties determined on the freshly purified sample were as follows, boiling point, $34.076 \pm .003^{\circ} \mathrm{C}$; change of boiling point with change of pressure: $\frac{d t}{d P}=0.0382^{\circ} \mathrm{C}$ per millimeter of mercury; freezing point, $-146.8 \pm .2^{\circ} \mathrm{C}$; density at $20^{\circ} \mathrm{C}, 0.6805 \pm .0001 \mathrm{~g} / \mathrm{ml}$; refractive index at $20^{\circ} \mathrm{C}, 1.42160 \pm .00005$. The molecular refraction was calculated to be 25.39. The volume expansivity was measured over the entire range of temperature between the freezing point and normal boiling point, giving the following equations:

$$
\begin{aligned}
& V=V_{0}\left(1+1.393 \times 10^{-3} t+2.79 \times 10^{-6} t^{2}+4.31 \times 10^{-9} t^{3}-5.60 \times 10^{-12} t^{4}\right) \\
& \rho=0.7002-0.9754 \times 10^{-3} t-0.592 \times 10^{-6} t^{2}+0.525 \times 10^{-9} t^{3}+9.66 \times 10^{-12} t^{4},
\end{aligned}
$$

in which $V$ and $\rho$ are the volume and density, respectively, at the temperature $t$, and $V_{0}$ the volume at $0^{\circ} \mathrm{C}$. From the Clausius-Clapeyron equation the latent heat of vaporization at the normal boiling point was calculated to be $25.9 \pm .3$ $\mathrm{kj} / \mathrm{mole}$. The refractive index at any temperature from about $0^{\circ} \mathrm{C}$ to the boiling point may be calculated from the equation

$$
n_{D}=1.43472-0.656 \times 10^{-3} t \text {. }
$$

On standing, the isoprene was found to undergo a transformation, presumably oxidation and polymerization, as was indicated by changes in purity, boiling point, density, and refractive index.

\section{CONTENTS}

I. Introduction

II. Preparation and purification of sample

III. Physical properties

1. Degree of purity 885

2. Boiling point and its relation to pressure 886

3. Freezing point

4. Volume expansivity 888

5. Density

6. Calculation of heat of vaporization 889

7. Refractive index and molecular refraction 890

IV. Comparison with previous investigations

V. References....... 893

\section{INTRODUCTION}

Isoprene (2-methyl-1,3-butadiene) has been for many years a substance of very considerable interest in the study of rubber, since it has been shown to be the fundamental unit in the constitution of the rubber hydrocarbon. Isoprene polymerizes to form a product which

\footnotetext{
1 Guest worker at the National Bureau of Standards from the Polytechnic Institute, Warsaw, Poland.
} $106351-36-6$ 
is chemically more closely related to natural rubber than any other synthetic product $[9,20,33,35,48,53,56] .^{2}$ Furthermore, the destructive distillation of natural rubber yields as its two major products isoprene and dipentene (dl-1-methyl-4-isopropenyl-1-cyclohexene) in amounts far exceeding those of any other constituents $[4,30,56]$. Aside from its relation to rubber, isoprene is of interest because it is thought to be the basic substance in the natural synthesis of the terpenes and to play an important role in the formation of plant cells $[3,8,13,49,50,54]$.

An investigation of the chemical thermodynamics of rubber now in progress at the Cryogenic Laboratory of this Bureau includes a study of isoprene and its relationship to rubber. Measurements of heat capacity and heat of combustion are at present being made on isoprene for the purpose of calculating its entropy. A report covering these results is now being prepared. Similar measurements for rubber have already been reported [5].

Since samples of high purity were desired for this work, care was taken in the preparation and purification of the isoprene, and the resulting product is thought to represent an improvement in purity as compared with isoprene prepared by previous investigators. Furthermore, not all workers had realized the importance of working with freshly purified samples. Also it is now possible to take advantage of recent important improvements in the technique of measuring physical properties, especially boiling point and related properties. In view of the wide divergence of values for many of the commonly measured physical properties, as reported in the literature, it seems worth while to report the values here obtained with samples of high purity.

\section{PREPARATION AND PURIFICATION OF SAMPLE}

The isoprene was made by the cracking of dipentene vapor by means of the "isoprene lamp" method of Harries and Gottlob [22] as modified by Whitby and Crozier [55]. About 5.5 liters of crude isoprene was prepared which had a yellow color and possessed a sharp odor. It was then subjected to successive distillations. The vacuumjacketed column used was about $140 \mathrm{~cm}$ in height and included 40 bulbs with ball valves and side tubes, according to the design of Swiętosławski $[39,40]$. The column head included a dephlegmator and condenser with take-off so arranged that the reflux ratio could be adjusted by means of drop-counters. For the isoprene distillation a 15 to 1 ratio was generally maintained. Temperature changes were read to the nearest $0.001^{\circ} \mathrm{C}$ by means of a Beckmann-Swiętosławski mercury thermometer [41] immersed in a mercury well surrounded by vapor rising from the dephlegmator. Corrections in the distilling temperature of the isoprene were made for changes in barometric pressure by simultaneous observations of the boiling point of pure water in a barometric ebulliometer.

Three successive distillations were made, with a reduction of charge in each case to include only the most nearly constant-boiling part of the previous distillation. Isoprene was evidently present in far greater amounts than any other substance. "The impurities were

${ }^{2}$ The numbers in brackets here and elsewhere in the text refer to the numbered references at the end of this paper. 
very largely materials of boiling points lower than that of isoprene, some of them condensing only at the temperature of solid carbon dioxide. In the early fractions of the first distillation, water was distilled over in small amounts as a separate phase. When the first distillation was continued above the boiling point of isoprene, no significant approach to constancy of boiling point was obtained below $176^{\circ} \mathrm{C}$, the approximate boiling point of dipentene. It was therefore concluded that the cracking process had yielded practically no substances with boiling points between those of isoprene and dipentene, and that the crude isoprene had contained some unchanged dipentene.

The third and final distillation yielded $200 \mathrm{ml}$ of a product distilling: within a range of $0.01^{\circ} \mathrm{C}$. The sample was colorless and possessed only a slight odor. This fraction was thoroughly mixed and different portions were used immediately in the determination of physical properties, several measurements being: performed simultaneously.

\section{PHYSICAL PROPERTIES}

A number of previous observers have noted that isoprene on standing for months or years at room temperature under atmospheric conditions will oxidize and polymerize [1, 11, 12, 26, 44, 55]. For this reason the physical properties here reported were determined as soon as possible after the final distillation. With the exception of the freezing point and expansivity, all measurements were made within 5 hours after the end of the final distillation. The sample used in the freezing-point determination had been kept in a refrigerator at about $8^{\circ} \mathrm{C}$ for 2 days, while that used in determining the expansion was several weeks old.

The expansivity, however, is thought to change only slightly with change in purity. In order to obtain some idea of the rate of polymerization, a sample which had been kept at $8^{\circ} \mathrm{C}$ for 2 months was distilled, and a solid residue amounting to less than 0.5 percent of the weight of the sample was obtained.

\section{DEGREE OF PURITY}

Swiętosławski [42] has set up for comparative purposes an arbitrary scale for the degree of purity of liquids. This scale is based on the measurement of $\Delta t$, the difference between the temperature of the boiling liquid and the temperature of the condensing vapor as determined in a differential ebulliometer of standard dimensions. For a pure substance $\Delta t$ is zero, and increases with increased concentration of impurities.

The freshly prepared sample of isoprene from the third distillation was found to have a $\Delta t$ of $0.002^{\circ} \mathrm{C}$. This value falls within the limits of the fifth or highest degree on the purity scale (range from 0.000 to $0.005^{\circ} \mathrm{C}$ ). A sample of isoprene from the previous distillation was found to have a $\Delta t$ of $0.006^{\circ} \mathrm{C}$. Its purity then was of the fourth degree (range from 0.005 to $0.020^{\circ} \mathrm{C}$ ). This sample was left in the ebulliometer at room temperature for 2 weeks. At the end of this time its $\Delta t$ value had increased to $0.028^{\circ} \mathrm{C}$, and its purity had decreased to the third degree (range from 0.020 to $0.050^{\circ} \mathrm{C}$ ). This increase in $\Delta t$ is direct confirmation of the expected decrease in purity brought about by oxidation and polymerization of the isoprene. Changes with time in other physical properties as mentioned below are other evidences of change in the material. 


\section{BOILING POINT AND ITS RELATION TO PRESSURE}

The normal boiling point of isoprene was determined in the ebulliometer used for the purity determination, following the comparative method of Swiętosławski [43]. According to this procedure a second ebulliometer containing pure boiling water is connected, together with the first ebulliometer, to a closed system in which the pressure can be adjusted. Determinations of the boiling point, by observing the temperature of the boiling liquid in equilibrium with the vapor, were made for both liquids under at least three different pressures, including values both above and below $760 \mathrm{~mm}$ of mercury. The temperatures were measured with a Mueller [31] type of Wheatstone bridge and a resistance thermometer designed for precise temperature measurements [29], and calibrated in accordance with the procedure for the International Temperature Scale [10].

In order to obtain the normal boiling point of isoprene from the observations it was merely necessary to find the boiling point of isoprene under the pressure at which the boiling point of water would be exactly $100^{\circ} \mathrm{C}$, since that pressure is exactly $760 \mathrm{~mm}$ by definition of the temperature scale. This procedure avoids the loss of precision inherent in the corrections to be applied to the readings of a mercury barometer.

For a sufficiently small range of pressures near the normal boiling points the relation between $t_{s}$, the boiling point of an organic substance, and $t_{w}$, the boiling point of water under the same pressure, can be represented by a function of the second degree; hence its derivative, $\frac{d t_{s}}{d t_{w}}$, changes linearly with change of pressure when this pressure is defined by the boiling point of water [58]. It was found that the quotient of finite increments, $\frac{\Delta t_{s}}{\Delta t_{w}}$, evaluated at the midpoints of several small intervals, changed only about 0.2 percent for a $2^{\circ} \mathrm{C}$ change of $t_{w}$. The ratios $\frac{\Delta t_{s}}{\Delta t_{w}}$ were evaluated at the midpoints between $t^{\prime}{ }_{w}$ and $t_{w}$, and $t^{\prime \prime}{ }_{w}$ and $t_{w}$, respectively; $t_{w}$ being a measurement close to $760 \mathrm{~mm}$ pressure, $t^{\prime}{ }_{w}$ below, and $t^{\prime \prime}{ }_{w}$ above this pressure. The derivative $\frac{d t_{s}}{d t_{u}}$ at $100.000^{\circ} \mathrm{C}$ was obtained by interpolation. These values are given in table 1 . The normal boiling point, $t_{B}$, is then calculated [57] from the observed values of $t_{s}$ and $t_{w}$ by the equation

$$
t_{B}=t_{s}+\frac{d t_{s}}{d t_{w}}\left(100.000-t_{w}\right)
$$

The estimated probable error in the normal boiling point, $34.076^{\circ} \mathrm{C}$, based on three determinations of this kind, is $\pm 0.003^{\circ} \mathrm{C}$. 
TABLE 1.-Degree of purity, boiling point, and change of boiling point with change of pressure for several samples of isoprene

\begin{tabular}{|c|c|c|c|c|c|}
\hline$\Delta t^{\mathrm{a}}$ & Degree of purity & $\frac{d t_{s} \mathbf{b}}{d t_{w}}$ & $\begin{array}{l}\text { Boiling } \\
\text { point of } \\
\text { water }\end{array}$ & $\left(\frac{d t}{d P}\right)_{s}^{\circ}$ & $\begin{array}{c}\text { Normal } \\
\text { boiling } \\
\text { point of } \\
\text { isoprene } \\
\text { sample }\end{array}$ \\
\hline $\begin{array}{c}{ }^{\circ} \mathrm{C} \\
0.028 \\
.006\end{array}$ & $\begin{array}{l}\text { Third } \\
\text { Fourth-- }\end{array}$ & & ${ }^{\circ} \mathrm{C}$ & $\begin{array}{c}{ }^{\circ} \mathrm{C} / \mathrm{mm} \\
0.0383\end{array}$ & $\begin{array}{l}{ }^{\circ} \mathrm{C} \\
34.124 \\
34.102\end{array}$ \\
\hline .002 & Fifth.. & $\begin{cases}\text { d } & 1.0367 \\
\text { f } & 1.0359 \\
\text { h } & 1.0338\end{cases}$ & $\begin{array}{r}\text { e } 100.720 \\
\text { g } 100.000 \\
\text { i } 97.988\end{array}$ & .0382 & 34. 076 \\
\hline
\end{tabular}

a Difference between the boiling temperature of isoprene and its condensation temperature in a differential ebulliometer of standard dimensions.

$b$ Ratio of the change in boiling point of isoprene to that of water for the same change in pressure.

- Change of boiling point of isoprene per millimeter change of pressure at $760 \mathrm{~mm}$.

d At midpoint between $t_{s}$ and $t^{\prime \prime}{ }_{s}$.

- $\frac{t^{\prime \prime}{ }_{w}+t_{w}}{2}$.

f Interpolated value.

g Defining $760 \mathrm{~mm}$ pressure.

h At midpoint between $t^{\prime}$ and $t_{s}$.

$\frac{t^{\prime}{ }^{\prime}+t_{w}}{2}$.

The value of $\frac{d t}{d P}$, the change of boiling point of isoprene with change of pressure at $760 \mathrm{~mm}$ of mercury, was obtained by multiplying the value of the derivative $\frac{d t_{s}}{d t_{w}}$ at $760 \mathrm{~mm}$ by 0.369 , which is the value in degrees per millimeter for the change of boiling point of water at $760 \mathrm{~mm}$ [32]. The value for isoprene was thus found to be $0.0382^{\circ} \mathrm{C}$ per millimeter of mercury.

Table 1 also shows the data and results of these determinations. For the purpose of comparison some values are also given for samples of lower purity. Higher boiling points and larger values of $\frac{d t}{d P}$ are characteristic of less pure samples.

\section{FREEZING POINT}

The freezing point of isoprene was measured in accordance with the procedure of Mair [28], using apparatus essentially similar to that described by him.

The isoprene was contained in a double-walled glass tube, the inner space between the walls being evacuated. Temperatures were measured with the same platinum resistance thermometer used for the boiling-point determination. Mechanical stirring with a spiral wire surrounding the thermometer and operated by an electric motor was continued throughout the determination.

The data for the freezing- and melting-point determinations are plotted in figure 1. The freezing point, determined as the temperature of the intersection of the freezing curve with the normal cooling curve, agrees with the melting point determined in a similar manner from the melting and the normal warming curves. The estimated error in the value $-146.8^{\circ} \mathrm{C}$ is thought not to exceed $\pm .2^{\circ} \mathrm{C}$. The variation obtained in repeated observations on a single sample was considerably less than $0.2^{\circ} \mathrm{C}$ but was of this order between different 
samples. Preliminary results of somewhat less precise melting-point determinations made in the course of heat-capacity measurements on a different sample using quite different apparatus and technique gave a value of $-146.6^{\circ} \mathrm{C}$.

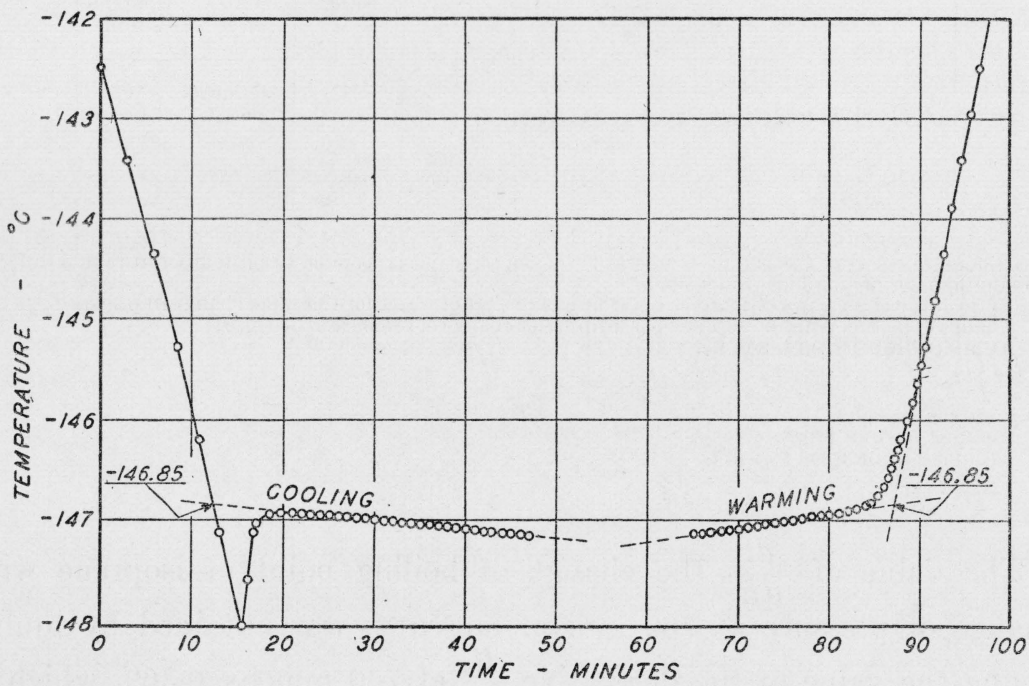

FIGURE 1.-Temperature measurements made on an isoprene sample passing through the liquid-solid transition, both cooling and warming.

\section{VOLUME EXPANSIVITY}

The volume expansivity, or temperature coefficient of volume expansion, $\frac{1}{V} \frac{d V}{d t}$, in which $V$ is the volume at the centigrade temperature $t$, was determined by dilatometer measurements extending from

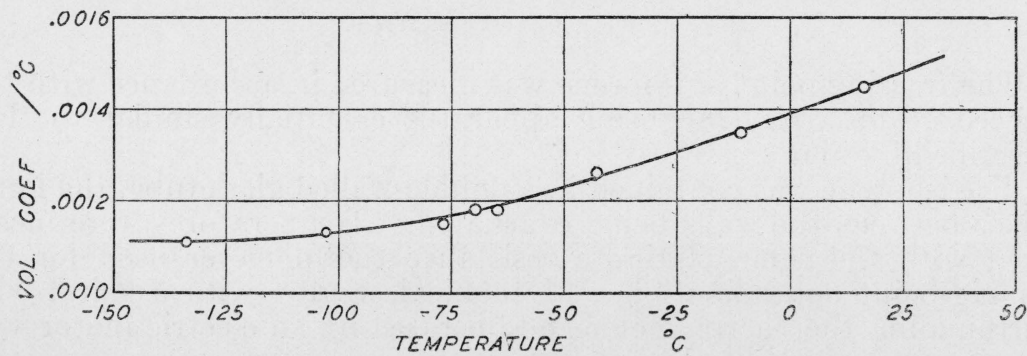

FIGURE 2.-Relation between the volume expansivity, $\frac{1}{V} \frac{d V}{d t}$, of liquid isoprene and temperature.

temperatures near the freezing point almost to the boiling point. The dilatometer, made of low-expansivity glass, had a bulb with a volume of $22.31 \mathrm{ml}$ capacity, joined to a capillary about $40 \mathrm{~cm}$ in length with an average volume of $0.02276 \mathrm{ml}$ per centimeter. A temperature range of about $20^{\circ} \mathrm{C}$ was covered in each run. For each run there was plotted a graph of the height of the liquid in the capillary as a 
function of the temperature. The temperature range was so small that no significant deviations from linearity over a single run could be observed. From the slope of the graph and the dilatometer dimensions the expansivity at the mean temperature of each run was calculated. These values have been plotted in figure 2, each point representing a separate run.

Four terms were necessary in a power series in order to express the expansivity to within 1 percent over the whole range of temperature, as given in the following equation:

$\frac{1}{V} \frac{d V}{d t}=-\frac{d \rho}{\rho d t}=1.393 \times 10^{-3}+3.63 \times 10^{-6} t+5.35 \times 10^{-9} t^{2}-38.8 \times 10^{-12} t^{3}$

For temperatures above $-100^{\circ} \mathrm{C}$ this equation yields values agreeing with the observed expansivity to better than 0.5 percent. An integration of the preceding equation, together with the expansion of an exponential, leads to the following equation:

$$
V=V_{0}\left(1+1.393 \times 10^{-3} t+2.79 \times 10^{-6} t^{2}+4.31 \times 10^{-9} t^{3}-5.60 \times 10^{-12} t^{4}\right)
$$

in which $V_{0}$ is the volume at $0^{\circ} \mathrm{C}$.

\section{DENSITY}

The density of a sample of the purest isoprene was determined by E. R. Smith of this Bureau, using a quartz picnometer of a type previously described $[36,51]$. The temperature was thermostatically controlled at $20.00 \pm .02^{\circ} \mathrm{C}$. Since the picnometer had a capillary of about $0.1 \mathrm{~mm}$ diameter and was closed with a ground-glass joint, the evaporation correction, made by extrapolation of the observed change of weight with time, was very small. The value actually obtained for the density was $0.68053 \mathrm{~g} / \mathrm{ml}$. In view of the uncertainties caused by the change of the material with time, as noted below, the value is rounded off and reported as $0.6805 \pm .0001 \mathrm{~g} / \mathrm{ml}$. From the density of the isoprene at $20^{\circ} \mathrm{C}$ and the expansivity data, the following equation may be derived for the density, $\rho$, of liquid isoprene at any temperature, $t$ :

$$
\rho=0.7002-0.9754 \times 10^{-3} t-0.592 \times 10^{-6} t^{2}+0.525 \times 10^{-9} t^{3}+9.66 \times 10^{-12} t^{4} .
$$

After storage for 24 hours at $8^{\circ} \mathrm{C}$ the value obtained for the same sample at the same temperature had risen from 0.6805 to 0.6808 $\mathrm{g} / \mathrm{ml}$. Values on the two succeeding days were 0.6814 and 0.6819 $\mathrm{g} / \mathrm{ml}$, respectively. This continuous rise in density is further evidence of the change brought about by oxidation and polymerization.

\section{CALCULATION OF HEAT OF VAPORIZATION}

The Clausius-Clapeyron equation can be used for the calculation of the latent heat of vaporization of isoprene when the previously determined constants are used together with the specific volume of the vapor at the boiling point. Measurements of the specific volume have not been made, but an approximate value can be calculated. Normal pentane and isopentane are the liquids most similar to isoprene for which data on critical temperatures and pressures are available. For each of these at the boiling point the "reduced temperature" [27], or ratio of temperature to critical temperature, is about 0.65. Also for each of these at the normal boiling point the "reduced pressure", 
or ratio of pressure to critical pressure, is about 0.030 . Since there is very little difference in the "reduced" states at the boiling point for similar organic compounds, these may be presumed to be the approximate values for isoprene at its boiling point.

Lewis [27] has recently published graphs, applicable to any hydrocarbon with more than three carbon atoms per molecule, which yield as a function of the "reduced" states the value of $\mu$, defined as $P V \mid R T$, in which $P$ and $V$ are respectively the pressure and volume of 1 mole of vapor, $R$ is the universal gas constant, and $T$ the absolute temperature. For the above values of the "reduced" temperature and pressure, Lewis' graph indicates a value of 0.96 for $\mu$. In other words, at the boiling point the specific volume of isoprene vapor is 96 percent of the specific volume of an ideal gas of the same molecular weight and at the same temperature and pressure. (Direct observations on $n$-pentane and isopentane at their boiling points, yield values of $\mu$ within 1 percent of 0.96 .) The specific volume of an ideal gas of the same molecular weight as isoprene at $34.076^{\circ} \mathrm{C}$ and under a pressure of $760 \mathrm{~mm}$ is $371 \mathrm{ml} / \mathrm{g}$. The specific volume of isoprene vapor under the same conditions is therefore $356 \mathrm{ml} / \mathrm{g}$.

In the Clausius-Clapeyron equation

$$
L=\frac{T\left(V_{0}-V_{l}\right)}{\frac{d t}{d P}}
$$

$L$ is the latent heat of vaporization of $1 \mathrm{~g}$ of liquid; $T$, the boiling point, $307.2^{\circ} \mathrm{K} ; V_{v}$, the specific volume of the vapor, $356 \mathrm{ml} / \mathrm{g}$; $V_{l}$, the specific volume of the liquid calculated from the previous values for density and expansivity, $1.5 \mathrm{ml} / \mathrm{g}$; and $\frac{d t}{d P}$, the rate of change of boiling point with change of pressure as previously measured, $0.0382^{\circ} \mathrm{C}$ per millimeter (or $28.7 \times 10^{-6}{ }^{\circ} \mathrm{C}$ per dyne $/ \mathrm{cm}^{2}$ ). The latent heat of vaporization of isoprene at the normal boiling point is thus calculated to be $380 \mathrm{j} / \mathrm{g}(90.8 \mathrm{cal} / \mathrm{g})$ or $25.9 \mathrm{kj} / \mathrm{mole}(6.17$ $\mathrm{kcal} / \mathrm{mole})$. Because of the uncertainty in the value of the specific volume of the vapor the estimated probable error in the calculation is \pm 1 percent.

The Bingham-Nernst modification [6] of Trouton's rule is

$$
\frac{L_{m}}{T_{B}}=17+0.011 T_{B}
$$

in which $L_{m}$ is the molal latent heat of vaporization in calories, and $T_{B}$ the absolute temperature of the boiling point. The right-hand member of the equation has the value 20.4, and the left-hand member 20.1. The rule in this form appears to be valid for isoprene within the limits of precision of determination of the heat of vaporization. This is taken as evidence that isoprene in the liquid form is not associated.

\section{REFRACTIVE INDEX AND MOLECULAR REFRACTION}

Measurements of refractive index at temperatures from 9 to $30^{\circ} \mathrm{C}$ were made with a water-jacketed Abbe refractometer (Valentine model) calibrated with distilled water. The values obtained are plotted in figure 3 , from which the refractive index at $20^{\circ} \mathrm{C}$ is found to be $1.42160 \pm .00005$, and the change with change in temperature 
$-0.656 \times 10^{-3}$ per degree centigrade. Therefore, the index of refraction, $n_{D}$, at temperature, $t$, is

$$
n_{D}=1.43472-0.656 \times 10^{-3} t \text {. }
$$

This equation is applicable for liquid isoprene at least over the range from 9 to $30^{\circ} \mathrm{C}$ and probably over a wider range. The refractive indices of fractions boiling both below and immediately above the purest isoprene were lower than that of the isoprene. The property is, however, not sensitive to very small amounts of impurities having boiling points near that of isoprene, since the third distillation, which lowered $\Delta t$ from 0.006 to $0.002^{\circ} \mathrm{C}$, raised the refractive index only by about 0.00001 .

Oxidation and polymerization of the isoprene on standing, however, brought about progressive increases in refractive index. For the first

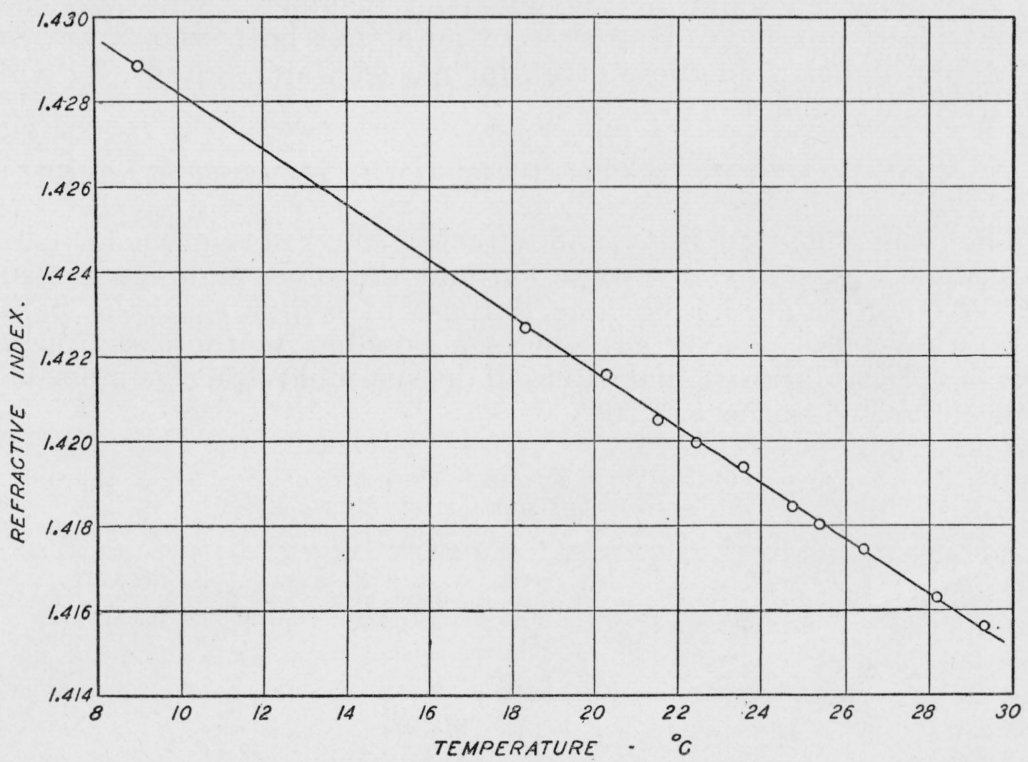

FIGURE 3.-Relation between the refractive index of isoprene and temperature.

few days the daily changes were of the order of 0.0002 . Later the rate of increase became considerably less, and rather variable. At the end of 2 months the total increase was about 0.00450 , and the material had become so lacking in homogeneity that further measurements were impossible.

The molecular refraction is often calculated by summing up the refractions of the individual atoms and adding a certain quantity for the "exaltation" due to double bonds or other special features of the structure. In the present case, however, no precise calculation is possible because the exaltation due to the conjugated double bond varies considerably from one compound to another. From the Lorenz-Lorentz formula, using the refractive index and density values as determined in this investigation, the molecular refraction is computed to be 25.39. By taking this value for the molecular refraction, and 2.490 and 1.066 for the atomic refractions of carbon and hydrogen, respectively, as reported by Swiętosławski [38], the exaltation due to the conjugated system in isoprene is 4.41. This is not greatly different 
from 4.32 for the conjugated system in 2,3-dimethyl-1,3-butadiene and 3.98 for chloroprene (2-chloro-1,3-butadiene).

The molecular refraction is commonly thought to be practically independent of temperature over moderate ranges. If this is true, differentiating the Lorenz-Lorentz equation gives in the resulting equation a relation between the change of refractive index with change of temperature and the expansivity.

$$
\frac{d n}{d t}=-\frac{\left(n^{2}+2\right)\left(n^{2}-1\right)}{6 n}\left(\frac{d V}{V d t}\right)
$$

At $20^{\circ} \mathrm{C}$ the observed expansivity is $1.467 \times 10^{-3}$ per degree centigrade and the observed refractive index is 1.42160 . These quantities yield a numerical value of $0.705 \times 10^{-3}$ for the right-hand member of the above equation. This is to be compared with $0.656 \times 10^{-3}$, the directly observed value of the left-hand member. This agreement is only fair, but it is of interest to note that both values are considerably higher than those given for most organic liquids, for which the average is about $0.45 \times 10^{-3}$.

\section{COMPARISON WITH PREVIOUS INVESTIGATIONS}

The boiling point, density, and refractive index of isoprene have been determined by many investigators, and the more significant results are given in table 2. For the purpose of comparison, the boiling points have been converted, wherever possible, to those at $760 \mathrm{~mm}$ pressure. Also the original values of density and refractive index have been converted to those at $20^{\circ} \mathrm{C}$.

TABLE 2.-Comparison of the data of various investigators on some physical properties of isoprene

\begin{tabular}{|c|c|c|c|c|c|c|}
\hline Observers & Year & $\begin{array}{l}\text { Refer- } \\
\text { ence } \\
\text { num- } \\
\text { ber }\end{array}$ & $\begin{array}{l}\text { Boiling point } \\
\text { at } 760 \mathrm{~mm}\end{array}$ & $\begin{array}{l}\text { Density } \\
\text { at } 20^{\circ} \\
\mathrm{C}\end{array}$ & $\begin{array}{l}\text { Refrac- } \\
\text { tive in- } \\
\text { dex at } \\
20^{\circ} \mathrm{C}\end{array}$ & $\begin{array}{l}\text { Freezing } \\
\text { point }\end{array}$ \\
\hline Williams & 1860 & [56] & 37 to $38^{\circ} \mathrm{C}$ & $\begin{array}{l}\mathrm{g} / \mathrm{ml} \\
0.6811\end{array}$ & & \\
\hline Tilden & 1882 & [4] & 34 to $35^{a}$ & & & \\
\hline Gladstone & 1886 & [18] & & 6681 & 1.4028 & \\
\hline $\begin{array}{l}\text { Thorpe and Jones } \\
\text { Thorpe and Rodger }\end{array}$ & $\begin{array}{l}1893 \\
1894\end{array}$ & {$[45]$} & 35.5 to $36.1^{a}$ & .6714 & ............. & \\
\hline Perkin & 1895 & {$[34]$} & $\{36$ & .6717 & $\cdots$ & \\
\hline Ipatiew ${ }^{\circ}$.. & 1897 & [24] & $\begin{array}{l}36 \text { to } 37-- \\
32 \text { to } 33 a\end{array}$ & $\begin{array}{l}.6696 \\
.6722\end{array}$ & 1. 40646 & \\
\hline Eule & 1897 & [16] & 33 to $39 a$ & & & \\
\hline and Courto & 1906 & [7] & $36^{a}$ & & & \\
\hline Harries and Gottlob_ & & [22] & 35 to 3 & & 141005 & \\
\hline Harries. . & 1911 & [21] & $37 a^{-\cdots-}$ & .6800 & 1. 42333 & \\
\hline Lebedew : & 1913 & [26] & 34.5 to $35.0^{\circ}$ & $\begin{array}{l}.6803 \\
.6803\end{array}$ & $\begin{array}{l}1.42019 \\
1.42207\end{array}$ & \\
\hline & 1913 & [25] & & .6803 & & \\
\hline Har & 1914 & [19] & 33. & .6832 & 1. 42387 & \\
\hline $\begin{array}{l}\text { Steir } \\
\text { Asch }\end{array}$ & 1914 & [37] & 33.5 & .6760 & 10150 & \\
\hline $\begin{array}{l}\text { Ascuan..-- } \\
\text { Enklaar... }\end{array}$ & $\begin{array}{l}1915 \\
1916\end{array}$ & {$[15]$} & 34.1 to 3 & .6811 & 1.41540 & “A \\
\hline Enklaar & 1916 & [14] & 33.9 & .6809 & 1. 41786 & - \\
\hline Waterm & 192 ra & [52] & & .6806 & 1.4194 & \\
\hline 1 Tongber & 1930 & [11] & $36 \mathrm{t}$ & .68 & & \\
\hline Heisig & 1931 & [23] & 33.7 to 34.1 & & & -.. \\
\hline $\begin{array}{l}\text { Farmer and Warre } \\
\text { Whitby and Crozie }\end{array}$ & $\begin{array}{l}1931 \\
1932\end{array}$ & {$[17]$} & $\begin{array}{l}34.4 \text { to } 35.8 \text {. } \\
34.0 \text { to } 34.5\end{array}$ & .6828 & 093 & \\
\hline Bekkedahl, Wood, and Wojciechowski. & 1936 & {$[00]$} & $34.076 \ldots \ldots$ & $.6805^{-}$ & 1.42160 & -146.8 \\
\hline
\end{tabular}

a Atmospheric pressure not recorded.

b Measurements made by Harries. See reference [21].

c Sample of isoprene obtained from Tilden. 
Because of inadequate knowledge of the purity of the samples of previous workers it is difficult to make a critical evaluation of the importance of their measurements. Incomplete removal of low-boiling impurities would be likely to lead to low values of the boiling point, density, and refractive index; oxidation and polymerization, on the other hand, to lead to high values. Almost all previous determinations of the boiling point have been observations of the range of temperature during distillation, and the values obtained depend greatly on the rate of distillation as well as the purity of the substance distilled, and give in most cases the condensation temperature. With such a low-boiling liquid superheating of the vapor is very probable, except in apparatus especially designed to avoid it.

The only freezing point determination recorded in the literature appears to be that of Enklaar [15], who made visual observations of a small sample attached to a pentane thermometer. The resulting value, given as "about $-120^{\circ} \mathrm{C}$ ", is considerably higher than that here obtained. Enklaar was unable to observe any distinct melting point.

The thermal expansion of isoprene was measured by Thorpe and Jones [45] in 1893 over a range of temperature from 0 to $32.6^{\circ} \mathrm{C}$. The volume relation is given as $V=V_{0}\left(1+1.4603 \times 10^{-3} t+0.99793 \times\right.$ $\left.10^{-6} t^{2}+56.0149 \times 10^{-9} t^{3}\right)$. The coefficient of $t$ is about 4 percent higher than the value here reported. The other coefficients show little correlation, probably because of the difference in the ranges of temperature involved.

Perkin [34] determined densities of his isoprene samples at various temperatures from 4 to $25^{\circ} \mathrm{C}$. From these values an expansivity of $1.43 \times 10^{-3}$ is obtained for a temperature of $12^{\circ} \mathrm{C}$. This is in very good agreement with the value 1.437 for the same temperature as calculated from the equation determined in this investigation.

The authors are glad to acknowledge the helpful cooperation and loan of equipment by several of the research associates of the American Petroleum Institute at this Bureau.

One of us ${ }^{3}$ expresses gratitude to the Polish Fundusz Kultury Narodowej (Polish Fund of National Culture), in Warsaw, for financial aid.

\section{REFERENCES}

[1] Aschan, Ann. Chem. 461, 1 (1928).

[2] Aschan, Öfvers Finska Vet. Soc. 58, 122 (1915) ; Chem. Abst. 14, 3654 (1920).

[3] Aschan, Ber. deut. chem. Ges. 55B, 2944 (1922); Chem.-Ztg. 49, 689 (1925).

[4] Bassett and Williams, J. Chem. Soc. 193\%, p. 2324.

[5] Bekkedahl and Matheson, J. Research NBS 15, 503 (1935) RP844. Reprinted in Rubber Chem. Tech. 9, 264 (1936).

[6] Bingham, J. Am. Chem. Soc. 28, 723 (1906).

[7] Blaise and Courtot, Bul. soc. chim. [3] 35, 989 (1906).

[8] Bogert, Chem. Rev. 10, 265 (1932).

[9] Bouchardat, Bul. soc. chim. 24, 108 (1875).

[10] Burgess, BS J. Research 1, 635 (1928) RP22.

[11] Conant and Tongberg, J. Am. Chem. Soc. 52, 1659 (1930).

[12] Conant and Peterson, J. Am. Chem. Soc. 54, 628 (1932).

[13] Emde, Helv. chim. acta 14, 888 (1931).

[14] Enklaar, Rec. trav. chim. 36, 216 (1916).

[15] Enklaar, Rec. trav. chim. 36, 247 (1916).

${ }_{3}$ Mieczysław Wojciechowski. 
[16] Euler, J. prakt. Chem. [2] 5\%, 131 (1898). Ber. deut. chem. Ges. 30, 1989 (1897).

[17] Farmer and Warren, J. Chem. Soc. 1931, p. 3221.

[18] Gladstone, J. Chem. Soc. 49, 609 (1886).

[19] Harries, Ber. deut. chem. Ges. 4 \% B, 1999 (1914).

[20] Harries, Ber. deut. chem. Ges. 35, 3256 (1902).

[21] Harries, Ann. Chem. 383, 157 (1911).

[22] Harries and Gottlob, Ann. Chem. 383, 228 (1911).

[23] Heisig, J. Am. Chem. Soc. 53, 3245 (1931).

[24] Ipatiew, J. prakt. Chem. [2]

[25] Kucherow, J. Russ. Phys. Chem. Soc. 45, 1634 (1913).

[26] Lebedew and Skawronski, J. Russ. Phys. Chem. Soc. 45, 1296 (1913); Bul. soc. chim. 16, 80 (1914); J. Soc. Chem. Ind. 33, 1224 (1914).

[27] Lewis, Ind. Eng. Chem. 28, 257 (1936).

[28] Mair, BS J. Research 9, 457 (1932) RP482.

[29] Meyers, BS J. Research 9, 807 (1932) RP508.

[30] Midgley and Henne, J. Am. Chem. Soc. 51, 1216 (1929). Reprinted in Rubber Chem. Tech. 2, 441 (1929).

[31] Mueller, Bul. BS 13, 547 (1916) S288.

[32] Osborne and Meyers, J. Research NBS 13, 1 (1934) RP691.

[33] Ostromysslenski, Chem. Zentr. 8\%, I, 973, 1068 (1916).

[34] Perkin, J. Chem. Soc. 6\%, 255 (1895).

[35] Pickles, J. Chem. Soc. 9\%, 1085 (1910).

[36] Smith and Wojciechowski, Roczniki Chem. 16, 104 (1936). Bul. int. acad. polonaise [A] (March 1936) (in English).

[37] Steimmig, Ber. deut. chem. Ges. 4\%A, 852 (1914).

[38] Swiętosławski, J. Am. Chem. Soc. 42, 1945 (1920).

[39] Swietosławski, J. chim. phys. 2\%, 329 (1930). Bul. soc. chim. [4] 49, 1563 (1931).

[40] Swiętosławski, Ebuljometrja, Kasy im Mianowskiego, Warszawa (1935). Ebulliometry, Mémoires de l'Académie Polonaise des Sciences et des Lettres [A] no. 3 (1936), Jagellonian University Press, Krakow (in English).

[41] Swwiętosławski, Roczniki Chem. 11, 545 (1931).

[42] Swiętosławski, IX Congreso int. Quim. Pura Aplicada Madrid, 2, 81 (1934). Bul. int. acad. polonaise [A] 504 (1930); 177 (1933). Compt. rend. 192, 1457 (1931). Roczniki Chem. 13, 176, 227 (1933). Chem. Listy 26, 442 (1932). J. Phys. Chem. 38, 1169 (1934).

[43] Swiętosławski, J. Phys. Chem. 2\%, 496 (1930).

[44] Thomas and Carmody, J. Am. Chem. Soc. 54, 2480 (1932); 55, 3854 (1933).

[45] Thorpe and Jones, J. Chem. Soc. 63, 273 (1893).

[46] Thorpe and Rodger, Trans. Roy. Soc. 185A, 397 (1894).

[47] Tilden, Chem. News 46, 120 (1882). J. Chem. Soc. 45, 410 (1884).

[48] Tilden, Chem. News 65, 265 (1892).

[49] Wallach, Ann. Chem. 238, 78 (1887).

[50] Wallach, Ber. deut. chem. Ges. 24, 1525 (1891).

[51] Washburn and Smith, BS J. Research 12, 305 (1934) RP656.

[52] Waterman and van Westen, Rec. trav. chim. 48, 1084 (1929).

[53] Weber, J. Soc. Chem. Ind. 13, 11 (1894).

[54] Weber, Ber. deut. chem. Ges. 33, 779 (1900).

[55] Whitby and Crozier, Can. J. Research 6, 203 (1932). Reprinted in Rubber Chem. Tech. 5, 546 (1932).

[56] Williams, Proc. Roy. Soc. 10, 516 (1860). Jahresber. 1860, p. $494 . \quad$ Chem. News 2, 206 (1860). Trans. Roy. Soc. 1860, p. 241. Phil. Mag. [4] 21, 463 (1861).

[57] Wojciechowski, J. Research NBS 17, 453 (1936) RP921.

[58] Zmaczynski, J. chim. phys. 27, 503 (1930). Roczniki Chem. 13, 181 (1933).

Washington, September 29, 1936. 